\title{
Effect of Achyranthes Aspera Leaf Extract on Hematological Parameters of Swiss Albino Mice
}

\author{
Emmanuel Asuquo Etim ${ }^{1,}$, Yusuf Abdulhakeem Adebayo ${ }^{1}$, Obeagu Emmanuel Ifeanyi ${ }^{2}$ \\ ${ }^{1}$ Department of Laboratory Services, Federal Medical Centre, Yola, Adamawa State, Nigeria \\ ${ }^{2}$ Department of University Health Services, Micheal Okpara University, Abia State, Nigeria
}

Email address:

emmasuti@yahoo.com (E. A. Etim)

${ }^{*}$ Corresponding author

\section{To cite this article:}

Emmanuel Asuquo Etim, Yusuf Abdulhakeem Adebayo, Obeagu Emmanuel Ifeanyi. Effect of Achyranthes Aspera Leaf Extract on Hematological Parameters of Swiss Albino Mice. World Journal of Public Health. Vol. 4, No. 4, 2019, pp. 96-101. doi: 10.11648/j.wjph.20190404.14

Received: May 9, 2018; Accepted: May 24, 2018; Published: December 10, 2019

\begin{abstract}
Background/Objective: Achyranthes aspera is an erect flowering medicinal herb use in folkloric medicine. This study aims to examine the effect of methanolic leaf extract of Achyranthes aspera on hematological parameters of Swiss albino mice. Materials and Methods: 70 adult mice of both sexes with mean weight of $22 \pm 5 \mathrm{~g}$ were used for this study. Achyranthes aspera leaves was pulverized to coarse powder from where methanolic extract was obtained. $0.2 \mathrm{ml}$ of $50 \mathrm{mg} / \mathrm{kg}, 100 \mathrm{mg} / \mathrm{kg}$, and $200 \mathrm{mg} / \mathrm{kg}$ respectively of leaf extract was administered to mice for four days. After administration, $1 \mathrm{ml}$ of blood was collected from mice through cardiac puncture into EDTA bottle for full blood count estimation using Abacus- 80 hematological analyzer. Results: The administration of $50 \mathrm{mg} / \mathrm{kg}, 100 \mathrm{mg} / \mathrm{kg}$ and $200 \mathrm{mg} / \mathrm{kg}$ doses of the extract resulted in increased lymphocyte count from $29.4 \pm 7.35 \%$ to $70.4 \pm 0.25 \%, 70.5 \pm 0.219 \%$ and $81.3 \pm 0.282 \%$ respectively at $\mathrm{P}>0.05$ while neutrophil value was reduced from $55.2 \pm 11.05 \times 10^{9} / 1$ to $14.0 \pm 0.216 \times 10^{9} / 1,11.2 \pm 0.109 \times 10^{9} / 1$ and $12.3 \pm 0.148 \times 10^{9} / 1$. The administration of $50 \mathrm{mg} / \mathrm{kg}, 100 \mathrm{mg} / \mathrm{kg}$ and $200 \mathrm{mg} / \mathrm{kg}$ doses of the extract increases platelet count from $99.0 \pm 0.52 \times 10^{3} / \mathrm{ul}$ to $529 \pm 0.01 \times 10^{3} / \mathrm{ul}$, $332 \pm 0.523 \times 10^{3} / \mathrm{ul}$ and $135 \pm 0.543 \times 10^{3} / \mathrm{ul}$ respectively. Conclusion: Ingestion of methanolic leaf extract of Achyranthes aspera resulted in a dose dependent changes in hematological parameter of albino mice including significant increase in lymphocyte and platelet counts. This plant's leaf extract may therefore have the potentials of being effective in the treatment of diseases cause by thrombocytopenia and lymphocytopenia in mammals. It is believed that information provided in this study can enhance appropriate usage of Achyranthes aspera in folkloric medicine in Nigeria.
\end{abstract}

Keywords: Achyranthes Aspera, Hematological Parameter, Albino Mice

\section{Introduction}

Achyranthes aspera is an annual, erect stiff flowering herb, usually about 0.3 to 1 meter high $[1,2]$ and belong to Amaranthaceae family. It is commonly found as a way side weed in most tropical regions of the world. Achyranthes aspera have since been documented to have a wide application in folkloric medicine globally and it has been reported that various parts of this plant are used traditionally for treatment of various health problems such as: treatment of wounds, [3] fever, [4] dysentery, asthma, [5] gonorrhea [6] and hydrated Paste of this plant's roots is used in ophthalmia and opacities of the cornea [7] . A. aspera leaves have also been shown to have cancer preventive activity [8] and it has been shown that extracts of this plant exhibits antiarthritic, laxative, ecbolic, immuno-stimulant, [9] antihelminthic, aphrodisiac, antiviral, mosquito larvicidal, [10] antitrypanosomal, [11] anticoagulant, diuretic [12, 13] and antiparasitic [14] characteristics including Hepatoprotective ability. [15] In addition, available medical literatures indicates that, various alcoholic extract of stem, leaves and flower of Achyranthes aspera possesses molluscicidal, [16] antimicrobial, [17] anti-inflammatory, [18] Anti-oxidant, [19] Anti-depressant, [6, 20] anti-allergic, [21] antiimplantation, abortifacient activities [22] as well as dose dependent contraceptive and antifertility properties in rats [23, 24] and also, extract of this plant have been known to improve 
the haemostatic system of mammals. [25] The pharmacomedical effects of this plant is believed to be due to the present of certain phytochemicals such as: saponins, [26] $\beta-D$ galactopyranosyl ester of D-Glucuronic Acid (also known as saponins B) and D-Glucuronic Acid (saponins A). [27] In male reproductive medicine model, A. aspera roots have been reported to possess spermicidal activity in both human and rat [28] and administration of A. aspera leaves extracts causes reduction in spermatogenesis, steroidogenesis, androgen production, and alteration of sexual behavior in Swiss albino mice. [29] Albino mice are one of the two white-colored varieties of the domesticated house mouse, Mus musculus, and according to scientific American report, Albinism in mice is the result of a single genetic color factor being lost, which leads to a loss of pigmentation in the skin and eyes. The hematological parameters of mice considered in this study includes: Packed Cell Volume (PCV), Total White Cell Count (tWBC), lymphocyte count, neutrophil count, monocyte count, hemoglobin level, platelet count and red blood cell count.

Herbal drugs constitute a major part of many traditional medical systems globally [7] and Plants (including A. aspera) can still serve as possible sources for new drugs and therapeutic chemicals [28] but literature on the effect of A. aspera extract on hematological parameters of mammals is scanty, and effect of this plant's leaf extract on the hematological parameter of albino mice in Northeastern Nigeria have not yet been fully studied therefore, this study aims to examine the effect of methanolic leaf extract of Achyranthes aspera on the hematological parameter of mice in other to elucidate the patho-hematological effects and hematotoxicity of this plant in traditional medicinal care. It is believed that the information obtained in this study will enhance safe and appropriate use of Achyranthes aspera in folkloric medicine in Nigeria.

\section{Materials and Methods}

This study was carried out in Adamawa Hospital Yola, Adamawa state in Nigeria. 70 adult Swiss albino mice of both sexes with mean weight of $22 \pm 5 \mathrm{~g}$ were used for this study. The mice were obtained from Nigerian National Institute of Veterinary Research, VOM, Plateau state, and the mice were acclimatized for six weeks in colony cages $(5$ mice per cage) under standard laboratory conditions (12h light/dark cycle), fed with standard commercial pellet diet and given access to water ad libitum.

Fresh leaves of Achyranthes aspera were collected from bushes in Yola town. The leaves were washed, dried and pulverized to coarse powder. $100 \mathrm{~g}$ of the powder was soaked in $500 \mathrm{ml}$ of $70 \%$ methanol for 72 hours; the mixture was further filtered using filter paper (Whatman No. 1) to obtain methanolic leaf extract. Chemical tests were carried out on the methanolic extracts to identify its phytochemical constituents using standard procedures. [30-32]

The extract was administered to mice through intragastric route using the stomach tube to ensure adequate ingestion. The dose level of the extract was calculated based on the weight of mice using the formula:

$$
\text { Dose }=\frac{\text { body weight } \mathrm{x} \text { required volume }}{100}
$$

The mice were divided into five groups comprising of three experimental, one toxicity (further divided into five) and one negative control groups. The experimental group was administered with $0.2 \mathrm{ml} \mathrm{of} 50 \mathrm{mg} / \mathrm{kg}, 100 \mathrm{mg} / \mathrm{kg}, 200 \mathrm{mg} / \mathrm{kg}$ body weight respectively of methanol leaf extract of Achyranthes aspera for four days per dose. The negative control group was administered with $0.2 \mathrm{ml}$ of distilled water, while the toxicity group was used for acute toxicity test. After administration, $1 \mathrm{ml}$ of blood was collected from the mice through cardiac puncture into EDTA bottle and used for hematological analysis. Full blood count was estimated in the blood using Abacus- 80 hematological analyzer.

\subsection{Statistical Analysis}

Statistical analysis was performed using the SPSS (Statistical Package for Social Sciences) 20.0 software (Chicago IL). Descriptive values were given as mean standard error of mean. Categorical variables were expressed as the number of cases and the percentage value. One-way ANOVA was used to compare mean results among and within groups. All data was analyzed at confidence interval of $p<0.05$ and $p>0.05$ as indicated in table 3 .

\subsection{Acute Toxicity}

Acute toxicity was determined on the leaf extract for dose level of $0 \mathrm{mg} / \mathrm{kg}, 500 \mathrm{mg} / \mathrm{kg}, 1500 \mathrm{mg} / \mathrm{kg} 2900 \mathrm{mg} / \mathrm{kg}$ and $4000 \mathrm{mg} / \mathrm{kg}$ respectively on mice using standard methods. $[33,34]$ The mice were monitored within $24 \mathrm{hrs}$ for signs of acute toxicity and mortality.

\subsection{Full Blood Count}

Using the Abacus- 80 machine, the procedure for blood cell (full blood count) determination was performed as follows: EDTA samples were placed in a hematology blood mixer for three minutes and the blood cells were automatically counted through a probe fitted in the Abacus- 80 machine. After one minutes, the results of the blood cell count were displayed on the color LCD screen of the machine. The hematological indices values of the negative control group were used as the reference range for the estimated parameters in this study.

\section{Results}

Table 1. Phytochemical constituents of the methanol plant extract.

\begin{tabular}{ll}
\hline Constituents & A. aspera \\
\hline Saponins & + \\
Phenols & - \\
Tanins & - \\
Flavonoids & + \\
Quinolones & - \\
Glycosides & - \\
Tarpenoids & + \\
Steroids & - \\
Alkaloids & + \\
\hline
\end{tabular}

KEY: - = Absent, $+=$ Present 
Chemical analysis of methanolic extract of leaf of Achyranthes aspera indicated the present of Saponins, Flavonoids, Alkaloids and Tarpenoids. However, Phenols,
Tanins, Quinolones and Glycosides were not detected in the methanol leaf extract of this plant in Northeastern Nigeria as shown in Table 1.

Table 2. Acute oral toxicity of methanolic leaf extract of Achyranthes aspera.

\begin{tabular}{llllll}
\hline Dose (mg/kg) & Dead & Treated & Latency (hrs) & Toxicity symptoms \\
\hline 0 & 0 & 2 & 24 & None \\
500 & 0 & 2 & 24 & None \\
1500 & 0 & 2 & 24 & None \\
3000 & 0 & 2 & 24 & None \\
4000 & 0 & 2 & 24 & None \\
\hline
\end{tabular}

Toxicity test indicated that none of the mice shows symptoms of acute toxicity for the period under observation as shown on table 2 .

Table 3. Effect of methanolic leaf extract of Achyranthes aspera on hematological parameters of swiss albino mice.

\begin{tabular}{|c|c|c|c|c|c|c|c|c|c|}
\hline & DOSE (mg/kg) & *PCV & *HGB & *WBCT & *Lymphocyte & *Neutrophil & *Monocyte & *Platelet & *RBC \\
\hline \multirow[t]{2}{*}{$\begin{array}{l}\text { Achyranthes } \\
\text { aspera }\end{array}$} & 50 & $39.3 \pm 0.233$ & $13.1 \pm 0.111$ & $10.2 \pm 0.132$ & $70.4 \pm 0.25$ & $14.0 \pm 0.216$ & $15.6 \pm 0.242$ & $529 \pm 0.512$ & $8.5 \pm 0.312$ \\
\hline & 100 & $41.6 \pm 0.356$ & $12.6 \pm 0.121$ & $7.7 \pm 0.081$ & $70.5 \pm 0.219$ & $11.2 \pm 0.109$ & $14.3 \pm 0.187$ & $332 \pm 0.523$ & $7.6 \pm 0.219$ \\
\hline $\begin{array}{l}\text { Negative } \\
\text { control (DW) }\end{array}$ & $1 \mathrm{ml}$ & $31.4 \pm 0.55$ & $9.7 \pm 0.22$ & $34.9 \pm 8.72$ & $29.4 \pm 7.35^{\#}$ & $55.2 \pm 11.05^{\#}$ & $8.4 \pm 0.41$ & $99.0 \pm 0.52$ & $5.4 \pm 0.29$ \\
\hline
\end{tabular}

Data are expressed as mean $\pm \mathrm{SEM}, * \mathrm{P}<0.05{ }^{*} \mathrm{P}>0.05$

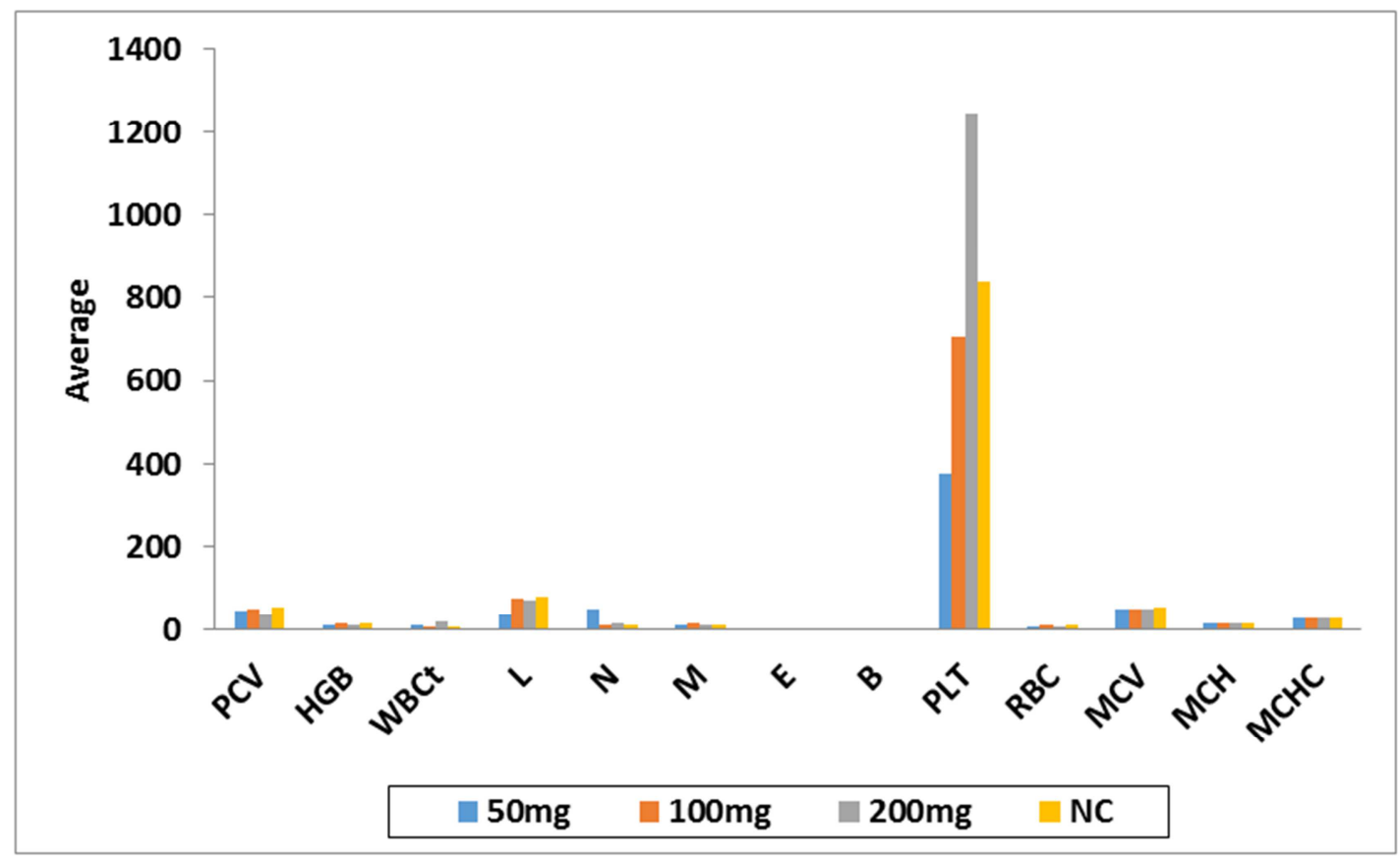

$\mathrm{NC}=$ Negative Control $=1 \mathrm{ml}$ water

Figure 1. The chart of the effect of methanolic leaf extract of Achyranthes aspera on hematological indices of albino mice.

Table 3 indicates that varying doses of methanolic extract of leaf of Achyranthes aspera had multiple effects on hematological parameters of albino mice. The alteration in the hematological indices was observed to be dependent on the dosage of the extract. The administration of $50 \mathrm{mg} / \mathrm{kg}$ of the extract increases the PCV value from $31.4 \pm 0.55 \%$ to $39.3 \pm 0.233 \%$ while the administration of $200 \mathrm{mg} / \mathrm{kg}$ and $100 \mathrm{mg} / \mathrm{kg}$ increases the PCV (Packed Cell Volume) value from $31.4 \pm 0.55 \%$ to $41.6 \pm 0.356 \%$ at $\mathrm{P}<0.05$ (Table 3)
However, the administration of $50 \mathrm{mg} / \mathrm{kg}$ and $100 \mathrm{mg} / \mathrm{kg}$ of the extract increases the hemoglobin (HGB) value from $9.7 \pm 0.22$ to $13.1 \pm 0.111 \mathrm{~g} / \mathrm{dl}$ and $12.6 \pm 0.121 \mathrm{~g} / \mathrm{dl}$ respectively but when $200 \mathrm{mg} / \mathrm{kg}$ dose was ingested, the hemoglobin value did not show significant change. On the other hand, total white blood cell count (WBCT) was reduced from $34.9 \pm 8.72 \times 10^{9} / 1$ to $10.2 \pm 0.132 \times 10^{9} / 1,7.7 \pm 0.081 \times 10^{9} / 1$ and $5.2 \pm 0.158 \times 10^{9} / 1$ after ingestion of $50 \mathrm{mg} / \mathrm{kg}, 100 \mathrm{mg} / \mathrm{kg}$, and $200 \mathrm{mg} / \mathrm{kg}$ of the extract respectively. On the contrary, the 
ingestion of the $200 \mathrm{mg} / \mathrm{kg}$ dose of the extract resulted in very high level of lymphocyte count up to $81.3 \pm 0.282 \%$ and the dose of $50 \mathrm{mg} / \mathrm{kg}$ and $100 \mathrm{mg} / \mathrm{kg}$ resulted in increase of lymphocyte value from $29.4 \pm 7.35 \%$ to $70.4 \pm 0.25 \%$ and $70.5 \pm 0.219 \%$ at $\mathrm{P}>0.05$ while neutrophil value was reduced from $55.2 \pm 11.05 \times 10^{9} / 1$ to $14.0 \pm 0.216 \mathrm{x} 10^{9} / 1$, $11.2 \pm 0.109 \times 10^{9} / 1$ and $12.3 \pm 0.148 \times 10^{9} / 1$ after the administration of $50 \mathrm{mg} / \mathrm{kg}, 100 \mathrm{mg} / \mathrm{kg}$ and $200 \mathrm{mg} / \mathrm{kg}$ of the extract respectively at $\mathrm{P}>0.05$. The ingestion of $50 \mathrm{mg} / \mathrm{kg}$ and $100 \mathrm{mg} / \mathrm{kg}$ doses of the extract increases the value of monocyte from $8.4 \pm 0.41 \times 10^{9} / 1$ to $15.6 \pm 0.242 \times 10^{9} / 1$ and $14.3 \pm 0.187 \times 10^{9} / 1$ respectively but ingestion of $200 \mathrm{mg} / \mathrm{kg}$ of the extract reduces the monocyte level from $8.4 \pm 0.41 \times 10^{9} / 1$ to $6.4 \pm 0.147 \times 10^{9} / 1$.

Platelet value was also affected by dosage of the methanolic extract. Platelet and red blood cell value increases inversely as the dosage of the ingested extract increases as shown in table 3 . The administration of $50 \mathrm{mg} / \mathrm{kg}, 100 \mathrm{mg} / \mathrm{kg}$ and $200 \mathrm{mg} / \mathrm{kg}$ doses of the extract increases platelet level in the blood of mice from $99.0 \pm 0.52$ to $529 \pm 0.512 \mathrm{x} 10^{3} / \mathrm{ul}$, $332 \pm 0.523 \times 10^{3} / \mathrm{ul}$ and $135 \pm 0.543 \times 10^{3} / \mathrm{ul}$ respectively. Moreover, the value of red blood cell increases from $5.4 \pm 0.29 \times 10^{12} / 1$ to $8.5 \pm 0.312 \times 10^{12} / 1,7.6 \pm 0.219 \times 10^{12} / 1$ and $5.9 \pm 0.258 \times 10^{12} / 1$ after ingestion of $50 \mathrm{mg} / \mathrm{kg}, 100 \mathrm{mg} / \mathrm{kg}$ and $200 \mathrm{mg} / \mathrm{kg}$ of methanolic leaf extract of Achyranthes aspera respectively. In addition, of the eight hematological indices studied, lymphocyte and platelet counts values showed the highest increase value change after ingestion of the extract as shown in table 3 and figure 1 compare to other hematological parameters in the studied group.

\section{Discussion}

Effect of methanolic leaf extract of Achyranthes aspera on the blood of Swiss albino mice have been investigated and from this study, it was observed that, the ingestion of $500 \mathrm{mg} / \mathrm{kg}, 1500 \mathrm{mg} / \mathrm{kg}, 3000 \mathrm{mg} / \mathrm{kg}$, and $4000 \mathrm{mg} / \mathrm{kg}$ doses of methanolic extract of the leaf of Achyranthes aspera did not produce observable acute toxicity within the stipulated period of observation as shown in table 1. This demonstrates the level of toxically safety of this plant's extract and implies that methanolic extract of this plant's leaf at dosage below $4000 \mathrm{mg} / \mathrm{kg}$ may be toxically and clinically safe for intake by mammals and mice.

Chemical analysis of methanolic extract of Achyranthes aspera leaf indicated the present of certain phytochemicals such as: Saponins, Flavonoids, Alkaloids and Tarpenoids. However, Phenols, Tanins, Quinolones and Glycosides were not detected in the methanol leaf extract of this plant in Northeastern Nigeria as shown in Table 1. This is because some of the phytochemicals that are absent in this plant may be found in aqueous [35] not in methanolic medium that was used for the extract in this study and the present of Saponins, Flavonoids, Alkaloids and Tarpenoids phytochemicals in Achyranthes aspera have long been demonstrated by various researchers. [25, 26]

It is not yet clear which phytochemical mechanism resulted in the observed dose dependent alterations in hematological parameter of Swiss Albino mice, but increase value of lymphocyte after ingestion of the extract is believed to be due to the present of Saponins phytochemicals in this plant because Saponins have been shown to increase cytosolic calcium concentration which results in calcium permeable cation channels [36] and calcium play an important role in lymphocyte kinetics and proliferation [37] therefore, the present of Saponins may through the calcium activation mechanism improve lymphocytes proliferation in the blood. In addition, the dose dependent increase of blood lymphocyte counts as shown table 3 is also believed to be due to the presence of alkaloids as a phytochemical compound in the leaf extract of Achyranthes aspera since alkaloid fraction stimulate defense system by improving and modulating several immunological parameters including lymphocyte proliferation. [38]

The strong increase of lymphocyte count in the experimental group after ingestion of the provided dosage of methanolic leaf extract of this plant demonstrates that, this plant may have the potentials of improving the cellular immune system and may be effective in treatment of disease conditions cause by lymphocytopenia in mammals and in addition, there was a significant increase in platelet count value after ingestion of methanolic leaf extract of Achyranthes aspera although it is not yet clear of which mechanism resulted in increased thrombocyte in mice's blood but the dose-dependent increase in platelet count as a result of administration of extract of Achyranthes aspera leaf indicates that this plant's leaf extract may also have the potency to improve the hemostasis system in the management of bleeding disorders caused by thrombocytopenia in mammals.

\section{Conclusion}

The ingestion of methanolic leaf extract of Achyranthes aspera results in a dose dependent changes in hematological parameter of albino mice. The ingestion of $50 \mathrm{mg} / \mathrm{kg}$, $100 \mathrm{mg} / \mathrm{kg}$ and $200 \mathrm{mg} / \mathrm{kg}$ doses of methanolic extract of the leaf of Achyranthes aspera extract causes a significant increase in lymphocyte and platelet counts in blood of mice in the experimental group at $\mathrm{P}<0.05$. This plant leaf extract therefore has the potentials of being effective in the treatment of diseases cause by both thrombocytopenia and lymphocytopenia in mammals. It is believed that the information provided in this study will enhance the appropriate use of Achyranthes aspera in folkloric medicine in Nigeria.

\section{Disclaimer}

The views expressed in this article are that of the authors not an official position of any hospital or institution.

\section{Financial Sponsorship}

The study was not sponsored, the equipment used was provided by the hospital in which this work was done. 


\section{Conflict of Interest}

There is no conflict of interest regarding this work among the authors.

\section{Previous Publication}

This article has not been submitted to any journal for publication except the one being considered now.

\section{Acknowledgements}

The authors are sincerely grateful to the management and staff of the department of biochemistry, Moddibo Adama University Yola, and Adamwa hospital Yola for providing the environment and equipment for this research work.

\section{References}

[1] Geetha K. Antidiabetic activity of Achyranthes aspera L. with alloxanised mice for the estimation of level of glucose and cholesterol. Asian J. Plant Sci. Res. 2016; 6 (2): 18-23.

[2] Aziz A, Rahman M, Mondal AK. 3-Acetoxy-6benzoyloxyapagamide from Achyranthes aspera, Pharmaceutical J. 2005; 4: 1816-1820.

[3] S. Edwin, E. Jarald, D. L. Edwin, A. Jain, H. Kinger, K. R. Dutt, A. A. Raj. Wound healing and antioxidant activity of Achyranthes aspera. Pharmaceutical Biol. 2008; 46 (12), 824-828.

[4] N. G. Sutar, U. N. Sutar, Y. P. Sharma, I. K. Shaikh, S. S. Kshirsagar. Phytochemical investigation and pharmacological screening of Achyranthes aspera Lnn as analgesic and antipyretic. Biosci Biotech Res Asia. 2008; 5 (2): 841-844.

[5] B. R. Goyal, S. G. Mahajan, R. G. Mali, R. K. Goyal, A. A. Mehta. Hypoglycemic Effect of Achyranthes aspera L. Methanol Extract and Fractions on Streptozotocin-induced Diabetic Rats. Global J Pharmacolol. 2007; 1 (1): 6-12.

[6] C. C. Barua, A. Talukdar, S. A. Begum, B. Buragohain, J. D. Roy, R. S. Borah, M. Lahkar. Antidepresant-like effect of the methanolic extract of Achyranthes aspera Lnn in animal's models of depression. Pharmacologyonline, 2009; 2: 587-594.

[7] Saurabh Srivastav, Pradeep Singh, Garima Mishra, K. K. Jha, R. L. Khosa. Achyranthes aspera-An important medicinal plant: A review. J. Nat. Prod. Plant Resour. 2011; 1 (1): 1-14.

[8] Chakraborty Asima, Adelheid Brantner, Teruo Mukainaka, Yoshitoshi Nobukuni, Masahi Kuchide, Takao Konoshima, Harukuni Tokuda, Hoyoku Nishino. Cancer chemopreventive activity of Achyranthes aspera leaves on Esptein-Barr virus activation and two-stage mouse skin carcinogenesis. Cancer Letters. 2002; 177: 1-5.

[9] R. Chakrabarti, R. Y. Vasudeva. Achyranthes aspera stimulates the immunity and enhances the antigen clearance in catla catla. Intl Immunopharmacol. 2006; 6 (5): 782-790.

[10] A. Bagavan, A. A. Rahuman, C. Kamaraj, K. Geetha. Larvicidal efficacy of five cucurbitaceous plant leaf extract against mosquito species. Parasitol res. 2008; 103 (1): 223-229.

[11] Victoria O. A, C. A. Elusiyan, F. O. Olorunmola, F. B.
Adewoyin, N. O. Omisore A. O. Adepiti J. M. Agbedahunsi and C. O. Adewunmi. Evaluation of antitrypanosomal and anti-inflammatory activities of selected Nigerian medicinal plant in mice. Afr J Tradit Complement Altern Med. 2013; 10 (6): 469-476.

[12] Ratra PS, Misra KC. Seasonal variation in chemical composition of Achyranthes aspera Linn. and A. bidentata Bl. Indian Forester. 1970; 96 (5): 372-375.

[13] National Institute of Science Communication and Information Resources. The wealth of India, raw materials: a ready reckoner on biodiversity and bioresources of India. New Delhi: National Institute; 1985.

[14] A. A. Zahir, A. A. Rahuman, C. Kamaraj, A. Bagavan, G. Elango, A. Sangaran, B. S. Kumar. Parasitic effect of Achyranthes aspera. Parasitol Res. 2009; 105 (2): 453-461.

[15] A. R. Bafna, S. H. Mishra. Effect of methanol extract of achyranthes aspera linn. on rifampicin-induced hepatotoxicity in rats. Ars Pharmaceutica, 2004; 45 (4): 343-351.

[16] Belayhun M, Seid T, Yinebeb T, Argaw A. Molluscicidal effect of Achyranthes aspera L. (Amaranthaceae) aqueous extract on adult snails of Biomphalaria pfeifferi and Lymnaea natalensis. Infectious Dis of Poverty. 2017; 6: 133.

[17] Thilagavathi G, Kannaian T. Application of Pricklychaff (Achyranthes aspera Linn.) leaves as herbal antimicrobial finish for cotton fabric used in healthcare textiles. Natural Pro Rad. 2008; 7: 330-334.

[18] Vetrichelvan T, Jegadeesan M. Effect of alcohol extract of Achyranthes aspera Linn. on acute and sub-acute inflammation. Phytother Res. 2003; 17: 77-79.

[19] D. S. Gayathri, A. Archanah, P. Abiramasundari, V. Priya, K. Uma, T. Abirami. Antioxidant activity of commonly used vegetables. Indian J Nutr Diet. 2009; 46 (12), 485-490.

[20] C. C. Barua, S. A. Begum, A. Talukdar, D. C. Pathak, A. G. Barua, P. Borah, M. Lahkar. effect of achyranthes aspera linn on modified forced swimming in rats. Pharmacologyonline. 2010; 1: 183-191.

[21] S. B. Datir, A. B. Ganjare, S. A. Nirmal, S. B. Bhawar, D. K. Bharati, M. J. Patil. Pharmacologyonline. 2009; 921-925.

[22] Vasudeva N, Sharma SK. Post-coital antifertility activity of Achyranthes aspera Linn root. J Ethnopharmacol. 2006; 107: 179-181.

[23] Shibeshi W, Makonnen E, Debella A, Zerihun L. Phytochemical, contraceptive efficacy and safety Evaluations of the $\mathrm{MeOH}$ leaves extract of Achyranthes aspera L. in rats. Pharmacologyonline. 2006; 3: 217-224.

[24] Shibeshi W, Makonnen E, Zerihun L, Debella A. Effect of Achyranthes aspera L. on fetal abortion, uterine and pituitary weights, serum lipids and hormones. Afr Health Sc. 2006; 6 (2): 108-112.

[25] Bassey EO, Essien EE, Ching FP, Mbagwu HO. An Evaluation of the Sub Acute Toxicity and Haemostatic Effects of Leaves Extract of Achyranthes aspera in Mice and Albino Rats. EJMP.2015; 7 (1): 16-25.

[26] S. K. Sharma, N. Vasudeva, M. Ali. Indian Journal of Chemistry - Section B Organic and Medicinal Chemistry. 2009; 48 (8), 1164-1169. 
[27] Ram P. Rastogi, B. N. Mehrotra. Compendium of Indian Medicinal plants. Central Drug Research Institute, Lucknow and National institute of science communication and information resources, New Delhi. 2004; 5: 7-8, 11.

[28] Kamble A, Reddy C, Patil S. Testicular Activity of Mice Treated with $\mathrm{MeOH}$ Extract of Achyranthes aspera Leaves. J Adv Med Sc and Applied Technol. 2017; 3 (2); 93-100.

[29] Y. Tijani, M. O. Uguru, O. A. Salawu. Anti-Pyretic, AntiInflammatory and Anti-Diarrhoel Properties of Faidherbia Albida in Rats. Afr J Biotechnol, 2008, 7 (6), 696-700.

[30] Trease, GC and Evans, WC. (1989) textbook of pharmacology $13^{\text {th }}$ ed. ELBS, Bailliere Tindall, London, pp. 683-684.

[31] Harbone J. B, (1983) phytochemical methods. A guide to modern technique of plant analysis. Chapman and Hall, New York. Pp. 49-188.

[32] Dawit, D, Eyassu, M, Asfwa, D, Dawi, A, Kelbessa, U, Walleligen, M. In vivo anti-malaria activity of hydroalcoholic extract from Asparagus africanus Lam in mice infected with Plasmodium berghei. Ethiop J Health Dev. 2006; 20 (2): 112118.

[33] Victoria, CU, Ebele, AE, Obina, IE, Theophine, CO, Godwin, CA, Chukwuemeka, M. U. Antimalaria activity of aqueous exract and fraction of leaves of Agerantum conyzoides in mice infected with $P$. bergei. Int. J Pharmaceutical Sc. 2010; 2 (1): 33-38.

[34] Chung KT, Wong TY, Wei CI, Huang YW, Lin Y. Tannins and human health: a review. Crit Rev Food Sci Nutr. 1998; 38 (6): 421-464.

[35] Aniagu SO, Nwinyi FC, Akumka DD, Agbani EO, Dzama S, Ajoku GA, Izebe KS, Agala P, Adelusola KA, Ibe J, Uford I, Gamaniel KS Short-term toxicity studies of Ficus thonningii leaf extract in rats. Int. J. Food Technol. 2008; 43 (3): 456463.

[36] Lang E, Qadri SM, Lang F. Killing me softly: suicidal erythrocyte death. Int J Biochem Cell Biol. 2012; 44: 1236-1243.

[37] Etim EA, Emokpae MA, Medugu JT, Medugu FI. Correlation of lymphocyte count with serum calcium level and neutrophilto-lymphocyte ratio in end stage renal disease patients undergoing hemodialysis in Adamawa State, Nigeria. Int. J. Med. Med. Sci. 2017; 9 (5): 47-50.

[38] R. S. Bachhav, R. Sambathkumar. Evaluation of Immunomodulatory Activity of the Alkaloid Fraction of Trichopus zeylanicus Gaertn on Experimental Animals. Indian J Pharm Sci. 2016; 78 (1): 161-166. 